\title{
Comparative Studies of Cultural Characteristics of Rhizospheric and Non-rhizospheric Trichoderma spp. On Different Cultural Media
}

CHAITHRA M ( $\nabla$ chaithram06@gmail.com )

University of Agricultural Sciences https://orcid.org/0000-0001-5401-6399

N S Pankaja

University of Agricultural Sciences

\section{Research Article}

Keywords: Trichoderma spp., Rhizopheric, Non Rhizospheric, Mycelia growth rate, Sporulation rate

Posted Date: January 27th, 2022

DOI: https://doi.org/10.21203/rs.3.rs-1276282/v1

License: (c) (i) This work is licensed under a Creative Commons Attribution 4.0 International License.

Read Full License 


\section{Abstract}

Effect of different culture media was observed on rhizospheric and non-rhizospheric seven Trichoderma isolates. All the seven Trichoderma isolates were evaluated on seven different solid media for assessing growth and sporulation. Among the seven different solid media, corn meal agar media and oat meal agar media exhibited early sporulation and maximum mycelia growth rate of more number of Trichoderma isolates. Highest mycelia growth $(90 \mathrm{~mm})$ and early sporulation 48 hour after inoculation on maximum number of different solid media was observed by non rhizospheric isolates viz., PSV (Paddy straw) and GMV (Goat manure) over commercial isolate respectively than rhizospheric Trichoderma isolate (Rkd-Cu). So, apart from rhizospheric source we can use non rhizospheric source for isolation of effective Trichoderma isolates which we can future used as good biocontrol agents against different plant pathogens.

\section{Introduction:}

Trichoderma species are green-spored ascomycetes present in almost all types of tropical and temperate soils. They can regularly be found in the rhizosphere of plants and decaying plant material (Schuster and Schmoll 2010). They are opportunistic, avirulent plant symbionts are antagonistic against many phytopathogenic fungi. Trichoderma strains can be efficiently used to control diseases as a result of fungal pathogens viz., Phytophthora palmivora,Rhizoctonia solani, Fusarium spp., Sclerotium rolfsii and Pythium spp. (Tran, 1998; Nago et al., 2006) . In root, soil, and foliar habitats, they are highly interacting. Trichoderma spp. promotes plant growth and root development, crop yield, tolerance to abiotic stressors, and nutrient uptake and consumption, in addition to controlling phytopathogens. Harman and colleagues (Harman et al., 2004). Trichoderma spp. produces a variety of secondary chemicals, including polyketides, terpenes, and pyrones, which are antibacterial and antifungal antibiotics. Secondary metabolites perform a variety of roles in disease resistance, metal transport, differentiation, symbiosis, and spore generation and germination, to name a few (Demain and Fang, 2000). Similar to the hypersensitive response (HR), systemic acquired resistance (SAR), and induced systemic resistance (ISR) in plants, it enhances the production of resistance mechanisms. Tjamos et al., 1992; Benitez et al., 2004) Trichoderma spp. has been shown to boost lettuce, tomato, and pepper plant growth (Vinale et al., 2008). As biocontrol agents, microbial inoculants are effective and appealing options to avoid the inadequacies caused by a limited reliance on pesticides (Nakkeeran et al., 2002). Precision identification and characterisation of Trichoderma spp. are critical for realising the full potential of these fungi in specific applications (Lieckfeldt et al., 1999). Trichoderma sp. can be identified based on the morphology and colour of the colonies obtained on the potato dextrose agar medium. Trichoderma sp. has evolved various mechanisms that are involved in attacking other fungi. These mechanisms consist of mycoparasitism for production of inhibitory compounds, competition for space and nutrients, inactivation of the pathogen's enzymes and induced resistance. Physiological parameters such as temperature, moisture, $\mathrm{pH}$, and nutrients media have a significant impact on the potentiality of Trichoderma species. Media plays an important role in determining the effectiveness of Trichoderma 
against phytopathogens. Sharma et al., (2005) also observed that medium, $\mathrm{pH}$, and temperature had a significant impact on fungal growth and sporulation. Maurya et al. investigated the effect of different temperatures and culture conditions on ten Trichoderma viride (2017). The maximum growth of Trichoderma was found at $25-30^{\circ} \mathrm{C}$ and maximum weight was found in Potato dextrose agar (276 mg) and lowest was recorded in Czapek Dox broth $(96 \mathrm{mg})$. Apart from the effect of cultural studies on rhizospheric Trichoderma isolates, this paper presents comparative studies of cultural characteristics of rhizospheric and non rhizospheric Trichoderma spp. on different cultural media. Which gives the idea of the availability of different sources (other than soil rhizosphere) for selection of potential Trichoderma islates and their suitable best media for commercialization of strains.

\section{Materials And Methods:}

An experiment was conducted in the laboratory of Department of Plant Pathology, College of Agriculture V. C. Farm, Mandya, under University of Agriculture Sciences, Bengaluru, to evaluate the comparative cultural performance of rhizospheric and non rhizospheric Trichoderma spp. on different cultural media

Sample collection: Samples were collected by random sampling method from six different sources viz., soil rhizosphere, manures, coirpith, paddy straw, sawdust from different places of Mandya, Chamarajnagar, Davangere, Hassan and Tumkur district of Karnataka, India and were stored in a polyethylene bag and labeled.

Isolation and identification of Trichoderma spp. Trichoderma spp. were isolated by following serial dilution spread plate method using Trichoderma selective medium. The inoculated plates were incubated at $28 \pm 2{ }^{\circ} \mathrm{C}$ for about 5-7 days and observed for the appearance of Trichoderma colonies. Totally six were identified as Trichoderma spp. along with, one commercial isolate ( $T$. viride) for comparative studies (Table 1). Further isolates were maintained on slants for future uses.

Cultural characteristics features of Trichoderma isolates: The cultural characteristics viz., colour, mycelial form, number of concentric rings, days required to sporulate and mycelia growth rate of seven isolates were studied on seven solid media. The solid media were primed by adding agar to the medium. The selected media consisted of natural, synthetic and semi-synthetic sources. The list of media used in cultural studies of Trichoderma spp. is given in Table 2.

\section{Results And Discussion:}

Cultural studies of 7 isolates of Trichoderma spp. on seven different media: Colony appearance is one of the important cultural characteristics which helps in study the colony form, pigmentation, days required to sporulation.

SMV: SMV colony appeared dark green on CMA, TSM and SDA. Whereas on PDA and OMA white colony were recorded. Yellowish green colour was recorded in MEA. Even type of mycelial on PDA, OMA, TSM and MEA but uneven growth on CMA, V-8 and SDA. It produces green conidial production which was 
denser in center then towards the margin. 4 concentric rings were produced only on the MEA. However, no concentric rings were recorded on all six media. CMA, TSM and SDA sporulation was observed at 48h (2 days). In case of V-8 and MEA sporulate at $72 \mathrm{~h}$ (3days). whereas in PDA and OMA sporulate at $96 \mathrm{~h}$ (4days). Maximum colony diameter of $90.00 \mathrm{~mm}$ was recorded on potato dextrose, OMA and V-8 followed by $80.00 \mathrm{~mm}$ on SDA at $96 \mathrm{~h}$ (4days) after incubation (Table 3) (Fig. 1). However, the least mean colony diameter was observed on TSM $(15.00 \mathrm{~mm})$ followed by CMA $(61.67 \mathrm{~mm})$ and MEA $(71.67 \mathrm{~mm})$ (Table 4) (Fig. 8).

GMV: GMV isolate produced white mycelium growth on all the seven media later it to yellowish green and dark green at $5^{\text {th }}$ DAI. Whereas mycelial appeared even type of mycelial on all the media with green conidial production which was denser in center then towards the margin. It produces dark green colony appear on OMA, TSM and MEA. Whereas on PDA, CMA and V-8 greenish yellow colony were recorded. A maximum of 3 concentric rings was recorded on PDA followed by 2 concentric rings in CMA and one on CMA and V-8 juice agar. However, no concentric rings were recorded on MEA and SDA. In all the media GMV was sporulated at $48 \mathrm{~h}$ (2days) after incubation but on TSM sporulated at $72 \mathrm{~h}$ (3days) after incubation (Table 3) (Fig. 2). However, no sporulation was recorded on SDA. $90.00 \mathrm{~mm}$ mean colony diameter of was observed on CMA and malt extract agar, followed by of $89.67 \mathrm{~mm}$ on OMA and TSM. Least growth of $87.33 \mathrm{~mm}$ was recorded on SDA (Table 4) (Fig. 9).

PSV: The mycelia of PSV isolate was hyaline in all the seven media, later it turned to yellowish green to dark green in colour. The colony appeared flat and even on PDA, OMA, TSM and MEA medium but uneven growth was observed in CMA and V-8 media. In all the six media colony appeared green to dark green in colour. Whereas in V-8 colony was light yellow in colour. It produced two concentric rings on MEA, one concentric ring on PDA and OMA, however there were no concentric rings on the other media. In all the seven media the conidia was green in colour and was denser in center than towards the margin. The sporulation was observed at 48h after inoculation on PDA and CMA. In case of OMA and MEA sporulation were observed at $72 \mathrm{~h}$ after inoculation. However, no spores were recorded on V-8 juice medium even after $5 \mathrm{DAl}$. Sporulation on TSM and SDA were noticed at $96 \mathrm{~h}$ after inoculation (Table 3) (Fig. 3). The data revealed that the maximum colony diameter of $90.00 \mathrm{~mm}$ was recorded on all the six media by PSV isolate except in TSM where it was $33.33 \mathrm{~mm}$. A maximum mean colony diameter of 90.00 mm was observed on all media except on TSM (Table 4) (Fig. 10).

SDKd: The mycelia of SDKd isolate was hyaline in all the seven media, later it turned to yellowish green to dark green in colour. Uneven type of colony appeared on all the media except TSM and MEA. In CMA, MEA and SDA colony appeared dark green in colour whereas in OMA and TSM yellowish green mycelium was observed. In case of PDA and V-8, light yellow and colourless mycelium was recorded. It produced green conidial production was denser in center then towards the margin. A maximum of 3 concentric rings was recorded on CMA and SDA followed by 2 in MEA and one on PDA and OMA. However, no concentric rings were recorded on TSM and V-8 media. The sporulation was observed at $48 \mathrm{~h}$ (2 DAl) on MEA and SDA. Whereas in PDA, OMA and TSM sporulation was observed at $96 \mathrm{~h}$ (4 DAl). In CMA sporulation was observed at 72h (3 DAl) (Table 3) (Fig. 4). It produced maximum mean colony diameter 
(90.00 mm) on OMA and MEA media was recorded. This was followed by SDA (88.33). Least mean colony diameter was observed on TSM $(31.67 \mathrm{~mm})$ followed by CMA $(61.67 \mathrm{~mm})$ (Table 4) (Fig. 11).

CPV: CPV isolate produced white mycelium growth on all the seven media later it turned to yellowish green to dark green in colour at $5^{\text {th }}$ DAl. Colony appeared flat and even type of mycelial form on all the media with green conidia produced which was denser in center than towards the margin. It produced dark green colour colony on CMA and MEA. In case of PDA and OMA it produced white and green colour colony but in case of TSM, V-8 and SDA yellowish green, whitish yellow and transparent colony was recorded. Three concentric rings on OMA and CMA, two concentric rings on PDA followed by one concentric ring on V-8 and MEA were recorded. No concentric rings on the other media like TSM and SDA. It sporulated at $48 \mathrm{~h}$ after incubation in all the media but in case of PDA and V-8 sporulation was recorded at $72 \mathrm{~h}$ after incubation (Table 3) (Fig. 5). $90.00 \mathrm{~mm}$ mean colony diameter was recorded on PDA, OMA and MEA $(90.00 \mathrm{~mm})$ followed by CMA $(88.00 \mathrm{~mm})$ and V-8 juice $(87.33 \mathrm{~mm})$. However least growth was observed on TSM $(33.00 \mathrm{~mm})$ followed by SDA $(80.00 \mathrm{~mm})$ (Table 4) (Fig. 12).

RKd-Cu: RKd-Cu isolate appeared white mycelia on all the seven different media initially later yellowish green to dark green mycelia was recorded. Even type of mycelial growth on all media except on TSM and SDA where uneven growth was observed. It produces dark green conidia which was denser in center than towards the margin. In all the media colony appeared green to dark green colour except TSM, V-8 and SDA where colony was appeared to yellowish green, light yellow and colourless respectively. A maximum of 4 concentric rings was recorded on PDA and V-8 followed by 3 in CMA and MEA and 2 concentric rings on SDA and OMA. However, no concentric rings were recorded on TSM. Sporulation was observed on PDA, OMA and CMA at $48 \mathrm{~h}$ (2days) after incubation. In case of TSM, V-8 and MEA sporulation was observed at $72 \mathrm{~h}$ (3 days) after incubation. However, no sporulation was observed on SDA (Table 3) (Fig. 6). We recorded $90.00 \mathrm{~mm}$ on all the media except on CMA $(78.00 \mathrm{~mm})$ and $\mathrm{V}-8(66.67 \mathrm{~mm})$. The minimum was observed on TSM (11.00 mm) (Table 4) (Fig. 13).

Commercial isolate: The mycelia of commercial isolate ( $T$. viride) was hyaline in all the seven media, initially later it turned to yellowish green to dark green in colour. Flat and even type of colony was observed on all the different media with green conidia production which was denser in center than towards the margin. It produced dark green colour colony on CMA, TSM and MEA. In case of PDA and V-8 yellowish green colour was recorded. Whereas in OMA and SDA appeared light green and colourless colony was recorded. A maximum of 4 concentric rings was recorded on CMA followed by 3 on PDA and one on OMA and V-8. However, no concentric rings were recorded in SDA. At $48 \mathrm{~h}$ ( 2 days) spores were observed on PDA, CMA and MEA. Whereas, in OMA, TSM and V-8 sporulation were recorded at $72 \mathrm{~h}$ (3days). However, no sporulation was observed on SDA (Table 3) (Fig. 7). Minimum mean colony growth on Trichoderma specific medium $(13.00 \mathrm{~mm})$ followed by corn meal agar ( $80.00 \mathrm{~mm}$ ) (Table 4) (Fig. 14).

The above Studies revealed that all isolates showed dark green to light green mycelial colour on all the seven media but in case of SDA produced a transparent even growth. Similarly, all isolates of Trichoderma obtained from non rhizospheric sources produce spores at different DAI. SMV isolate 
sporulate at $48 \mathrm{~h}$ on TSM, CMA and SDA. GMV isolate produce spores at $48 \mathrm{~h}$ on all the media except TSM. In case of PSV isolate fast sporulation occurs on PDA and CMA. SDKd isolate sporulated early on MEA and SDA. CPV isolate sporulate at $48 \mathrm{~h}$ on OMA, CMA, MEA and TSM. Similarly, in case of rhizospheric source isolate RKd-Cu sporulate early on PDA and V-8. While, in case of commercial isolate earlier sporulation was observed on PDA, CMA and MEA.

Among the rhizospheric and non rhizospheric sources of Trichoderma isolate, GMV (non rhizospheric) have the capacity to produce the spores earlier ( $48 \mathrm{~h}$ ) on maximum number of solid media (5) compare with other isolates and commercial isolate. Almost all the isolates showed earlier sporulation on CMA. So, these results showed that CMA was best for occurrence of sporulation.

Almost all isolates produced varying number of concentric rings on media. Among them, SMV and RKd$\mathrm{Cu}$ isolate produced 4 concentric rings on PDA, V-8 and OMA respectively. Similarly, in commercial isolate produced 4 concentric rings on CMA followed CPV, GMV and SDKd produce 3 concentric rings. This data reveals that there is no difference in number of concentric rings produce by both rhizospheric and nonrhizospheric isolates. We also observed that there is no formation of concentric rings of all effective isolates on TSM. Results on colony appearance of Trichoderma spp. on different media are in conformity with Shah et al. (2012) wherein they reported that the colonies formed by T. harzianum and T. viride appeared dark green colonies with sufficient conidiation whereas, in T. Psuedokoningi colony formed almost whitish with little or no conidiation at $5^{\text {th }}$ DAI. However, $T$. harzianum appeared with more pigment mycelial growth than T. viridae. Further, they reported that T. Psuedokoningii produced no pigmentation at all.

In case of mycelia growth studies, rhizospheric isolate PSV exhibited maximum mycelial growth (90.00 $\mathrm{mm}$ ) on six different media compare with rhizospheric isolate RKd-Cu (4 media). Whereas, least colony diameter of all the isolates was seen on TSM. Among the different media OMA showed highest number of isolates exhibited maximum mycelia growth followed by MEA. Savitha et al. (2015) recorded that there was no significant difference in the growth rate among all the isolated Trichoderma spp. on potato dextrose agar and Malt extract agar except for Th16 which was slower on synthetic nutrient agar (80.00 $\mathrm{mm}$ ). It indicates that among these three media, potato dextrose agar was the best media for mycelial growth of Trichoderma spp.

In conclusion, Highest growth rate and early sporulation is the important characteristics of good biocontol agent. Among the different isolates, non rhizospheric source isolates shows highest growth rate (PSV) and early sporulation (GMV) on higher number of different media over commercial isolate. So, apart from rhizospheric source, we can use the non rhizospheric sources viz., goat manure, Sheep manure, Coir pith, Sawdust and Padystraw for isolation of good biocontrol agents against different plant pathogens.

\section{References:}


1. Benitez, T., Rincon, A. M., Limon, m. C. and Codon, A. C. (2004). Biocontrol mechanisms of Trichoderma strains. Int. Microbial., 7(4), 249-260.

2. Demain, A. L. and Fang, A. (2000) The natural functions of secondary metabolites. Advances Biochemi. Engineer. Biotechnol., 69: 1-39.

3. Harman, G. E., Howell, C. R., Viterbo, A., Chet, I. and Lorito, M. (2004). Trichoderma species opportunistic, avirulent plant symbionts. Nat. Rev Microbial., 2(1), 43-56.

4. Lieckfeldt, E., Samuels, G. J., Nirenberg, H. I. and Petrini, O. (1999). A morphological and molecular perspective of Trichoderma viride: is it one or two species? Appl. Environ. Microbiol., 65(6): 24182428 .

5. Maurya, M. K., Srivastava, M., Singh, A., Pandey, S. and Ratan, V. (2017). Effect of different temperature and culture media on the mycelia growth of Trichoderma viride isolates. Int. J. Curr. Microbiol. App. Sci., 6(2): 266-269.

6. Nago, B. H., Vu, D. N. and Tran, D. Q. (2006). Analyze antagonist effects of Trichoderma spp. for controlling southern stem rot caused by Sclerotium rolfsii on peanut. Plant Prot., 1:12-14.

7. Nakkeeran, S., A. S. Krishnamoorthy, V. Ramamoorthy and P. Renukadevi. (2002). Microbial inoculants in plant disease control. J. Ecobiol., 14(2): 83-94.

8. Savitha, M. J. and Sriram, S. (2015). Morphological and molecular identification of Trichoderma isolates with biocontrol potential against Phytophthora blight in red pepper. Pest. Manag. Hortic. Ecosyst., 21(2): 194-202.

9. Schuster, A. and Schmoll, M. (2010). Biology and biotechnology of Trichoderma. Appl. Microbiol. Biotechnol., 87: 787-799.

10. Shah, S., Nasreen, S. and Sheikh, P. A. (2012). Cultural and morphological characterization of Trichoderma spp. associated with green mold disease of Pleurotus spp. in Kashmir. Res. J. Microbiol., 7 (2): 139-144.

11. Sharma, R.L., Singh, B.P., Thakur, M.P. and Thapak, S.K. (2005). Effect of media, temperature, pH and light on the growth and sporulation of Fusarium oxysporum f. sp. lini. Ann. Pl. Protec. Sci., 13: 172174.

12. Tjamos, E. C., Papavizas, G. C and Cook, R. J. (1992). Biological control of plant diseases. Progress and challenges for the future. Plenum Press, New York.

13. Tran, T. T. (1998). Antagonistic effectiveness of Trichoderma against plant fungal pathogens. Plant Prot., 4: 35-38.

14. Vinale, F., Sivasithamparam, K., Ghisalberti, E. L., Marra, R., Woo, S. L. and Lorito, M. (2008). Trichoderma-plant-pathogen interactions. Soil. Biol. Biochem., 40(1): 1-10.

\section{Tables:}

Table 1: List of Trichoderma isolates collected from rhizosphere and non rhizosphere sources from different places 


\begin{tabular}{|lllll|}
\hline $\begin{array}{l}\text { SI. } \\
\text { No. }\end{array}$ & Source & $\begin{array}{c}\text { Isolate } \\
\text { code }\end{array}$ & Isolate name & $\begin{array}{c}\text { Place of } \\
\text { collection }\end{array}$ \\
\hline 1 & Sheep manure & SMV & Sheep manure V C Farm & V. C. Farm \\
\hline 2 & Goat manure & GMV & Goat manure V C Farm & V. C. Farm \\
\hline 3 & Paddy straw & PSV & Paddy straw V C Farm & V. C. Farm \\
\hline 4 & Saw dust & SDKd & Sawdust K M Doddi & K. M. Doddi \\
\hline 5 & Coir pith & CPV & Coir pith V C Farm & K. M. Doddi \\
\hline 6 & Soil rhizosphere & RKd-Cu & Rhizosphere K M Doddi- Cucumber & K. M. Doddi \\
\hline 7 & Commercial isolate & T. viride & Mandya Commercial isolate & Mandya \\
\hline
\end{tabular}

Table 2: List of media used to study the cultural characters of effective Trichoderma spp.

\begin{tabular}{|lll|}
\hline SI. No. & Solid media & Type of media \\
\hline 1 & Potato dextrose agar (PDA) & Semi- Synthetic \\
\hline 2 & Oat meal agar (OMA) & Semi- Synthetic \\
\hline 3 & Corn meal agar (CMA) & Semi- Synthetic \\
\hline 5 & Trichoderma specific medium (TSM) & Synthetic \\
\hline 6 & V-8 juice agar (V-8) & Semi-Synthetic \\
\hline 7 & Malt extract agar (MEA) & Non- Synthetic \\
\hline
\end{tabular}

Table 3: Colony characteristics of Seven isolates of Trichoderma spp. on Seven different media 


\begin{tabular}{|c|c|c|c|c|c|c|}
\hline Medium & Isolates & Colony colour & Pigmentation & Colony form & $\begin{array}{l}\text { Concentric } \\
\text { rings } \\
\text { (No.) }\end{array}$ & $\begin{array}{l}\text { Time taken } \\
\text { for } \\
\text { sporulation } \\
\text { (h) }\end{array}$ \\
\hline \multirow[t]{7}{*}{ PDA } & SMV & White & - & $\begin{array}{l}\text { Flat and even } \\
\text { growth }\end{array}$ & 0 & 96 \\
\hline & GMV & $\begin{array}{l}\text { Greenish } \\
\text { yellow }\end{array}$ & - & $\begin{array}{l}\text { Flat and even } \\
\text { growth }\end{array}$ & 3 & 48 \\
\hline & PSV & Dark green & - & $\begin{array}{l}\text { Flat and even } \\
\text { growth }\end{array}$ & 1 & 48 \\
\hline & SDKd & Light yellow & - & Uneven growth & 1 & 96 \\
\hline & CPV & $\begin{array}{l}\text { White and } \\
\text { green }\end{array}$ & - & $\begin{array}{l}\text { Flat and even } \\
\text { growth }\end{array}$ & 2 & 72 \\
\hline & RKd-Cu & Dark green & - & Even growth & 4 & 48 \\
\hline & T. viride & $\begin{array}{l}\text { Yellowish } \\
\text { green }\end{array}$ & - & Even growth & 3 & 48 \\
\hline \multirow[t]{7}{*}{ OMA } & SMV & White & - & $\begin{array}{l}\text { Flat and even } \\
\text { growth }\end{array}$ & 0 & 96 \\
\hline & GMV & Dark green & - & Even growth & 1 & 48 \\
\hline & PSV & Light green & Pale yellow & Even growth & 1 & 72 \\
\hline & SDKd & $\begin{array}{l}\text { Yellowish } \\
\text { green }\end{array}$ & - & Uneven growth & 1 & 96 \\
\hline & CPV & $\begin{array}{l}\text { White and } \\
\text { green }\end{array}$ & - & $\begin{array}{l}\text { Flat and even } \\
\text { growth }\end{array}$ & 3 & 48 \\
\hline & RKd-Cu & Dark Green & - & Even growth & 2 & 48 \\
\hline & T. viride & Light green & - & Even growth & 1 & 72 \\
\hline \multirow[t]{7}{*}{ CMA } & SMV & Dark green & - & Uneven growth & 0 & 48 \\
\hline & GMV & $\begin{array}{l}\text { Greenish } \\
\text { yellow }\end{array}$ & - & Even growth & 2 & 48 \\
\hline & PSV & Green & - & Uneven growth & 0 & 48 \\
\hline & SDKd & Dark green & - & Uneven growth & 3 & 72 \\
\hline & CPV & Dark green & - & Even growth & 3 & 48 \\
\hline & RKd-Cu & Dark green & - & Even growth & 3 & 48 \\
\hline & T. viride & Dark green & - & Even growth & 4 & 48 \\
\hline TSM & SMV & Dark green & - & Even growth & 0 & 48 \\
\hline
\end{tabular}




\begin{tabular}{|c|c|c|c|c|c|c|}
\hline & GMV & Dark green & - & Even growth & 1 & 72 \\
\hline & PSV & Green & - & Even growth & 0 & 96 \\
\hline & SDKd & $\begin{array}{l}\text { Yellowish } \\
\text { green }\end{array}$ & - & Even growth & 0 & 96 \\
\hline & CPV & $\begin{array}{l}\text { Yellowish } \\
\text { green }\end{array}$ & - & Even growth & 0 & 48 \\
\hline & RKd-Cu & $\begin{array}{l}\text { Yellowish } \\
\text { green }\end{array}$ & - & Even growth & 0 & 72 \\
\hline & T. viride & Dark green & - & Even growth & 0 & 72 \\
\hline V-8 & SMV & $\begin{array}{l}\text { White and } \\
\text { green }\end{array}$ & - & Uneven growth & 0 & 72 \\
\hline & GMV & $\begin{array}{l}\text { Greenish } \\
\text { yellow }\end{array}$ & - & Even growth & 2 & 48 \\
\hline & PSV & Light yellow & - & Uneven growth & 0 & - \\
\hline & SDKd & $\begin{array}{l}\text { White } \\
\text { transparent }\end{array}$ & - & Uneven growth & 0 & - \\
\hline & CPV & Light yellow & - & $\begin{array}{l}\text { Flat and even } \\
\text { growth }\end{array}$ & 1 & 72 \\
\hline & RKd-Cu & Light yellow & - & Uneven growth & 4 & 72 \\
\hline & T. viride & $\begin{array}{l}\text { Yellowish } \\
\text { green }\end{array}$ & - & Even growth & 1 & 72 \\
\hline MEA & SMV & $\begin{array}{l}\text { Yellowish } \\
\text { green }\end{array}$ & - & Even growth & 4 & 72 \\
\hline & GMV & Dark green & - & Even growth & 0 & 48 \\
\hline & PSV & Green & - & Even growth & 2 & 72 \\
\hline & SDKd & Dark green & $\begin{array}{l}\text { Yellowish } \\
\text { green }\end{array}$ & Even growth & 2 & 48 \\
\hline & CPV & Dark green & - & $\begin{array}{l}\text { Flat and even } \\
\text { growth }\end{array}$ & 1 & 48 \\
\hline & RKd-Cu & Green & - & Even growth & 3 & 72 \\
\hline & T. viride & Dark green & - & Even growth & 2 & 48 \\
\hline SDA & SMV & Dark green & - & Uneven growth & 0 & 48 \\
\hline & GMV & colourless & - & $\begin{array}{l}\text { Flat and even } \\
\text { growth }\end{array}$ & 0 & - \\
\hline & PSV & Green & - & Even growth & 0 & 96 \\
\hline & SDKd & Dark green & - & Uneven growth & 3 & 48 \\
\hline
\end{tabular}




\begin{tabular}{|ccclll|}
\hline CPV & colourless & - & Flat and even & 0 & - \\
growth & & Even growth & 2 & - \\
\hline RKd-Cu & colourless & - & Even growth & 0 & - \\
\hline T. viride & colourless & - & & \\
\hline
\end{tabular}

Table 4: Colony diameter of Seven isolates of Trichoderma spp. on Seven different media

\begin{tabular}{|c|c|c|c|c|c|c|c|c|}
\hline \multirow{2}{*}{$\begin{array}{l}\text { Sl. } \\
\text { No. }\end{array}$} & \multirow{2}{*}{$\begin{array}{l}\text { Medium/ } \\
\text { Treatments }\end{array}$} & \multicolumn{6}{|c|}{ Mean colony diameter in $\mathrm{mm}$} & \multirow[b]{2}{*}{ T. viride } \\
\hline & & SMV & GMV & PSV & SDKd & CPV & RKd-Cu & \\
\hline 1 & Potato dextrose agar & 90.00 & 89.00 & 90.00 & 71.67 & 90.00 & 90.00 & 90.00 \\
\hline 2 & Oat meal agar & 90.00 & 89.67 & 90.00 & 90.00 & 90.00 & 90.00 & 90.00 \\
\hline 3 & Corn meal agar & 61.67 & 90.00 & 90.00 & 61.67 & 88.00 & 78.33 & 80.00 \\
\hline 4 & $\begin{array}{l}\text { Trichoderma specific } \\
\text { medium }\end{array}$ & 15.00 & 89.67 & 33.33 & 31.67 & 16.67 & 12.00 & 13.00 \\
\hline 5 & V-8 juice agar & 90.00 & 89.00 & 90.00 & 85.00 & 87.33 & 66.67 & 90.00 \\
\hline 6 & Malt extract agar & 71.67 & 90.00 & 90.00 & 90.00 & 90.00 & 90.00 & 90.00 \\
\hline 7 & $\begin{array}{l}\text { Sabouraud's dextrose } \\
\text { agar }\end{array}$ & 80.00 & 87.33 & 90.00 & 88.33 & 80.00 & 90.00 & 90.00 \\
\hline \multicolumn{2}{|c|}{ S.Em \pm} & 0.89 & 0.89 & 0.79 & 1.67 & 1.67 & 1.02 & 0.38 \\
\hline \multicolumn{2}{|c|}{ CD@1\% } & 3.75 & 3.75 & 3.31 & 7.02 & 7.02 & 4.28 & 1.59 \\
\hline
\end{tabular}

Figures 

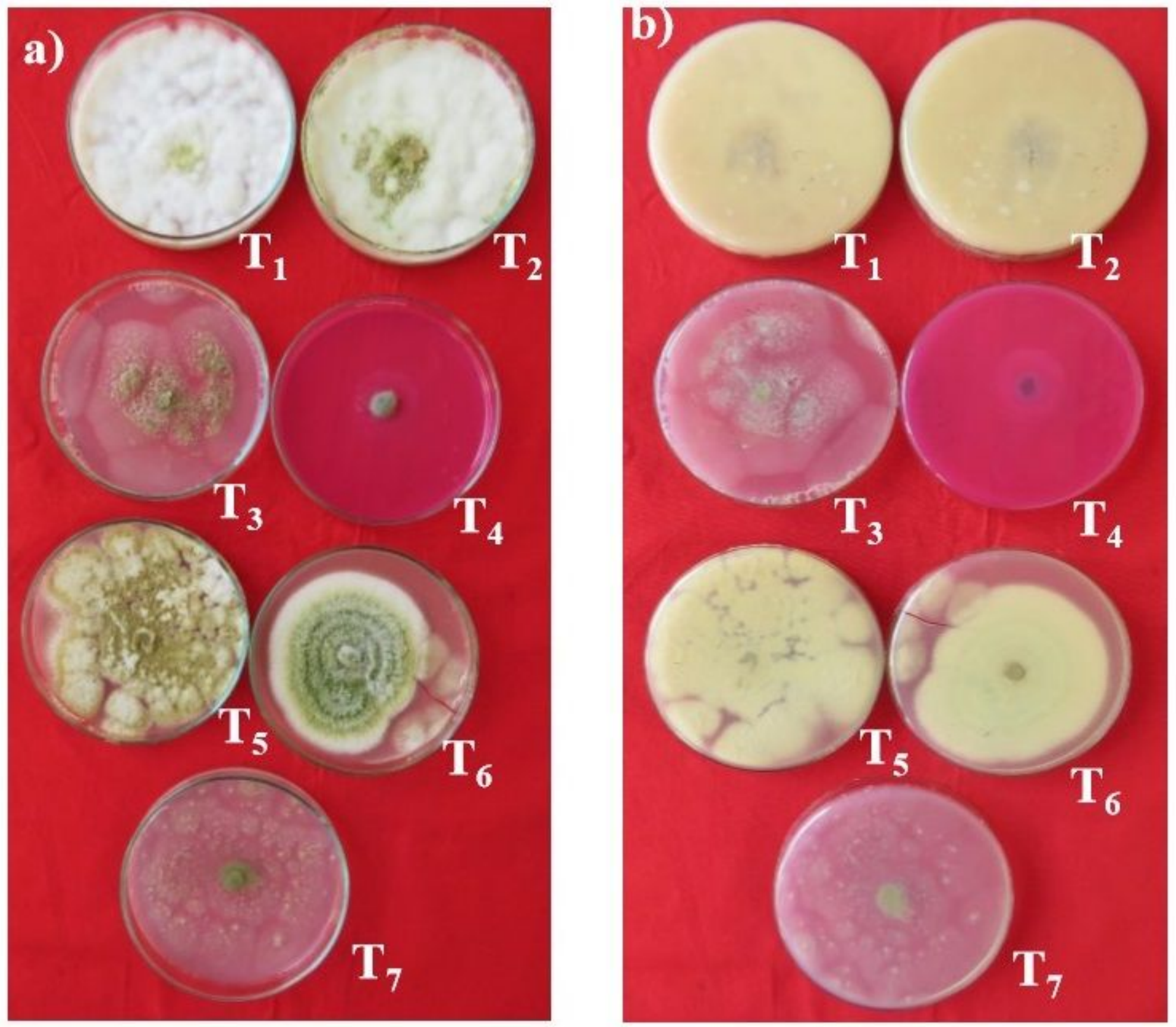

Figure 1

a) Colony appearance b) Pigmentation of SMV isolate on different media 

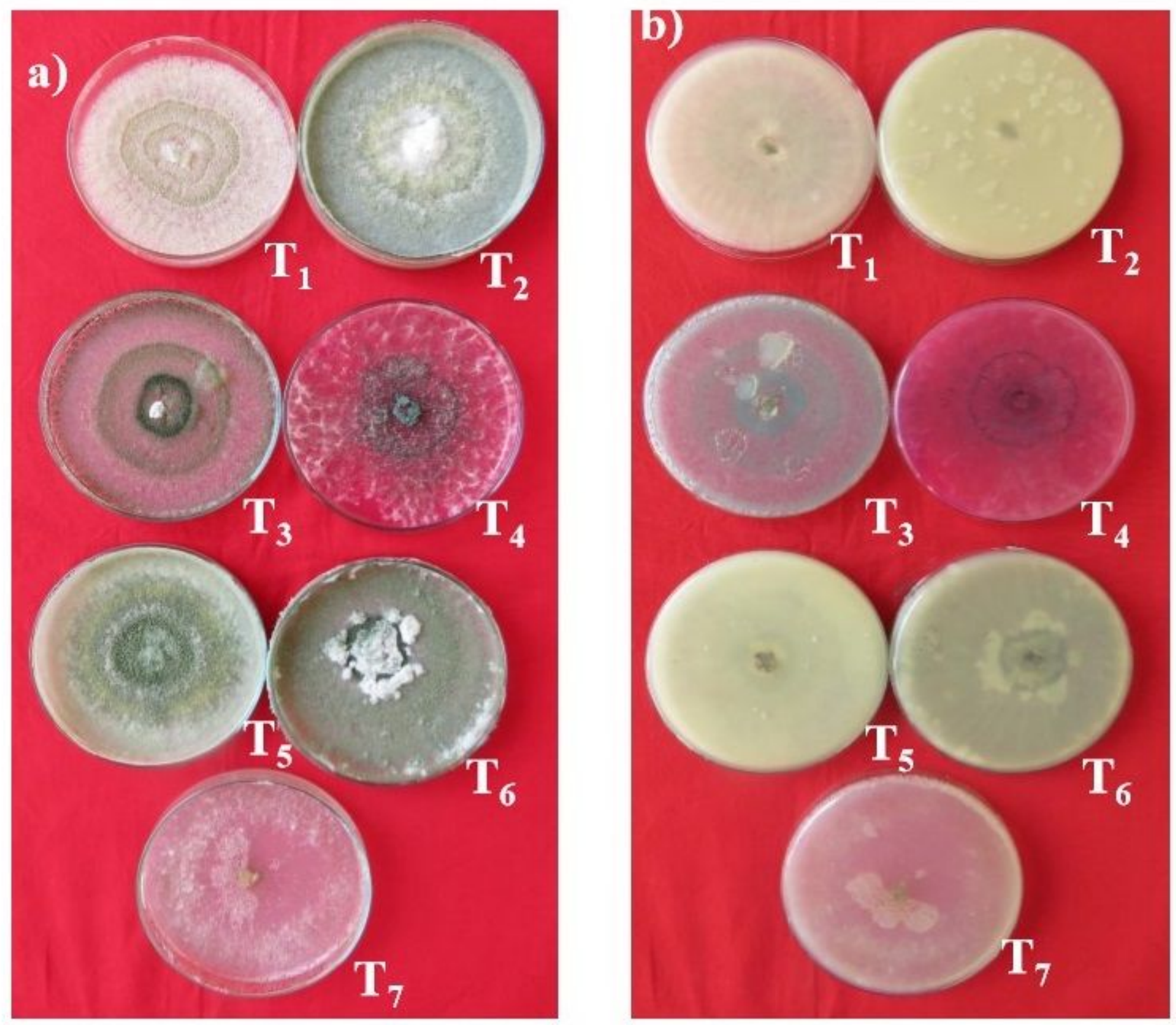

Figure 2

a) Colony appearance b) Pigmentation of GMV isolate on different media 

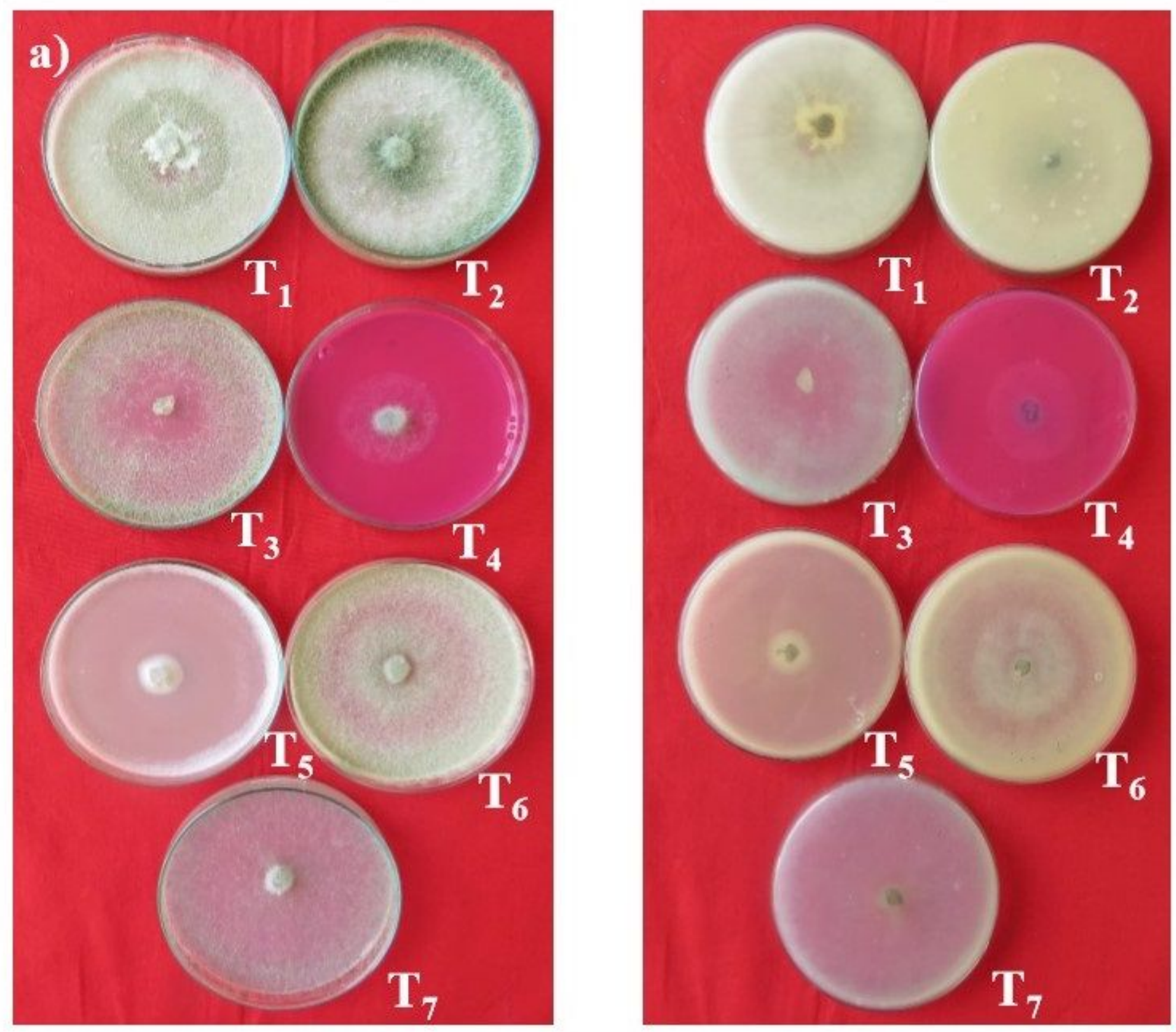

Figure 3

a) Colony appearance b) Pigmentation of PSV isolate on different media 

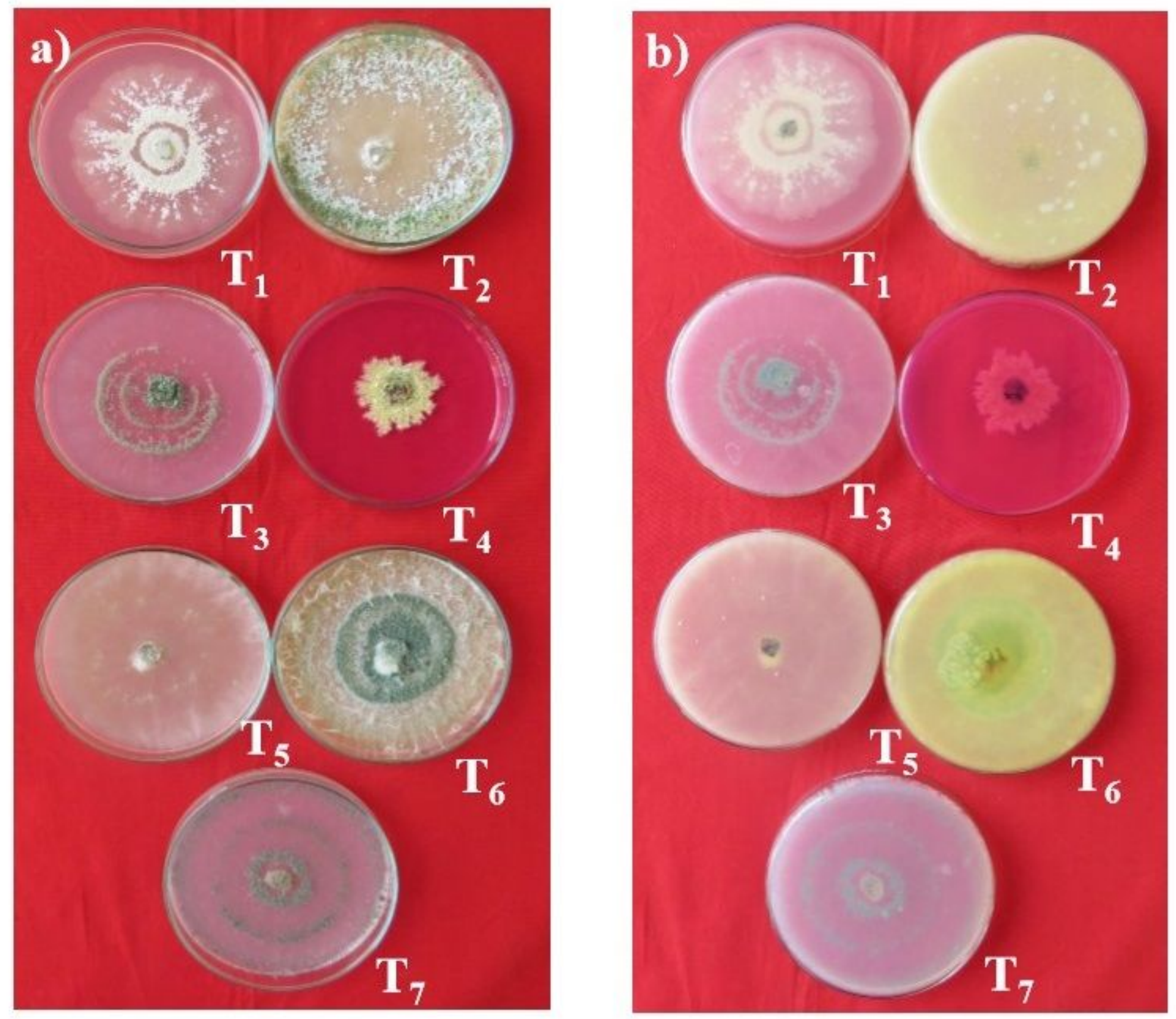

\section{Figure 4}

a) Colony appearance growth b) Pigmentation of SDKd isolate on different media 

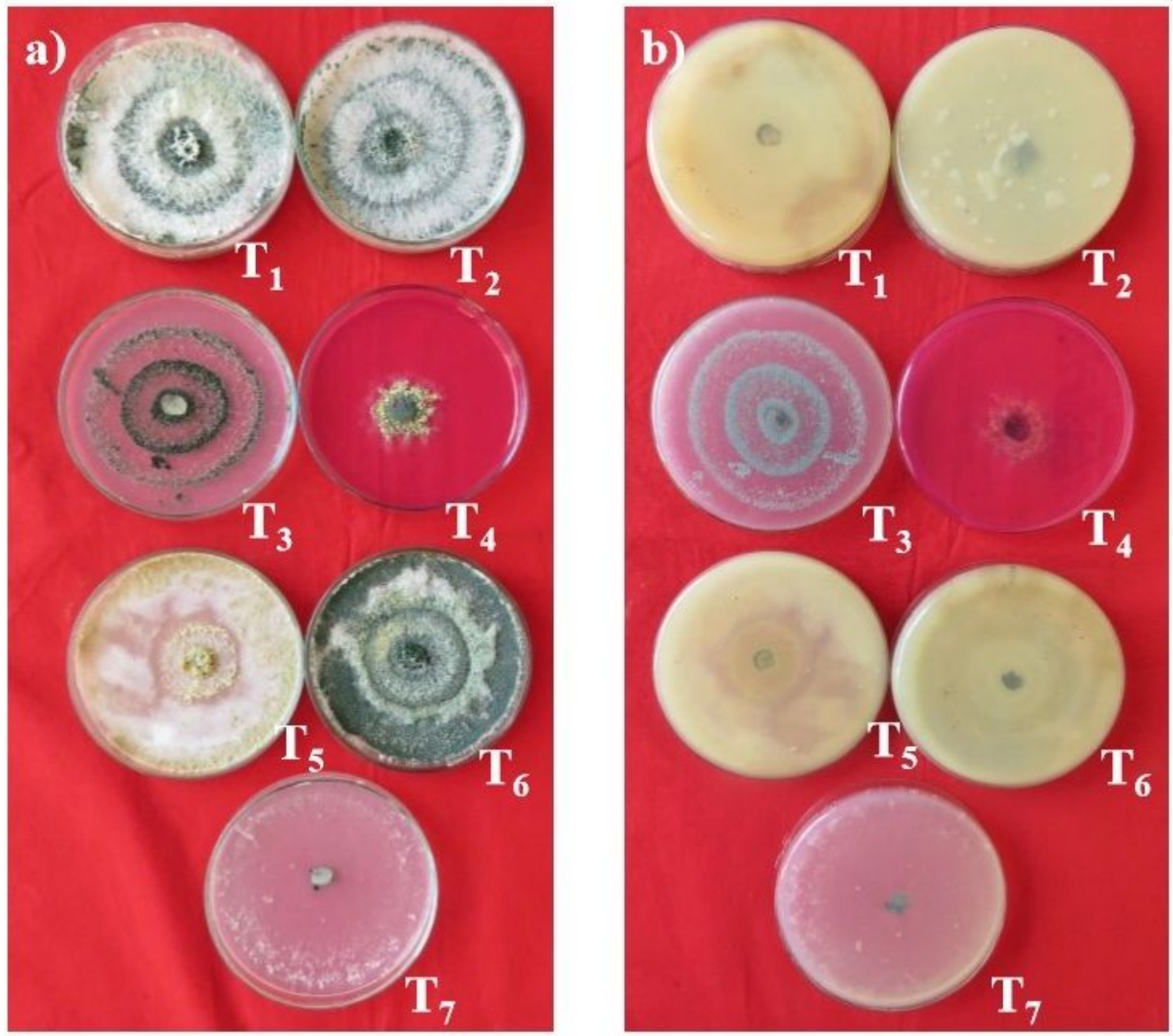

Figure 5

a) Colony appearance b) Pigmentation of CPV isolate on different media 

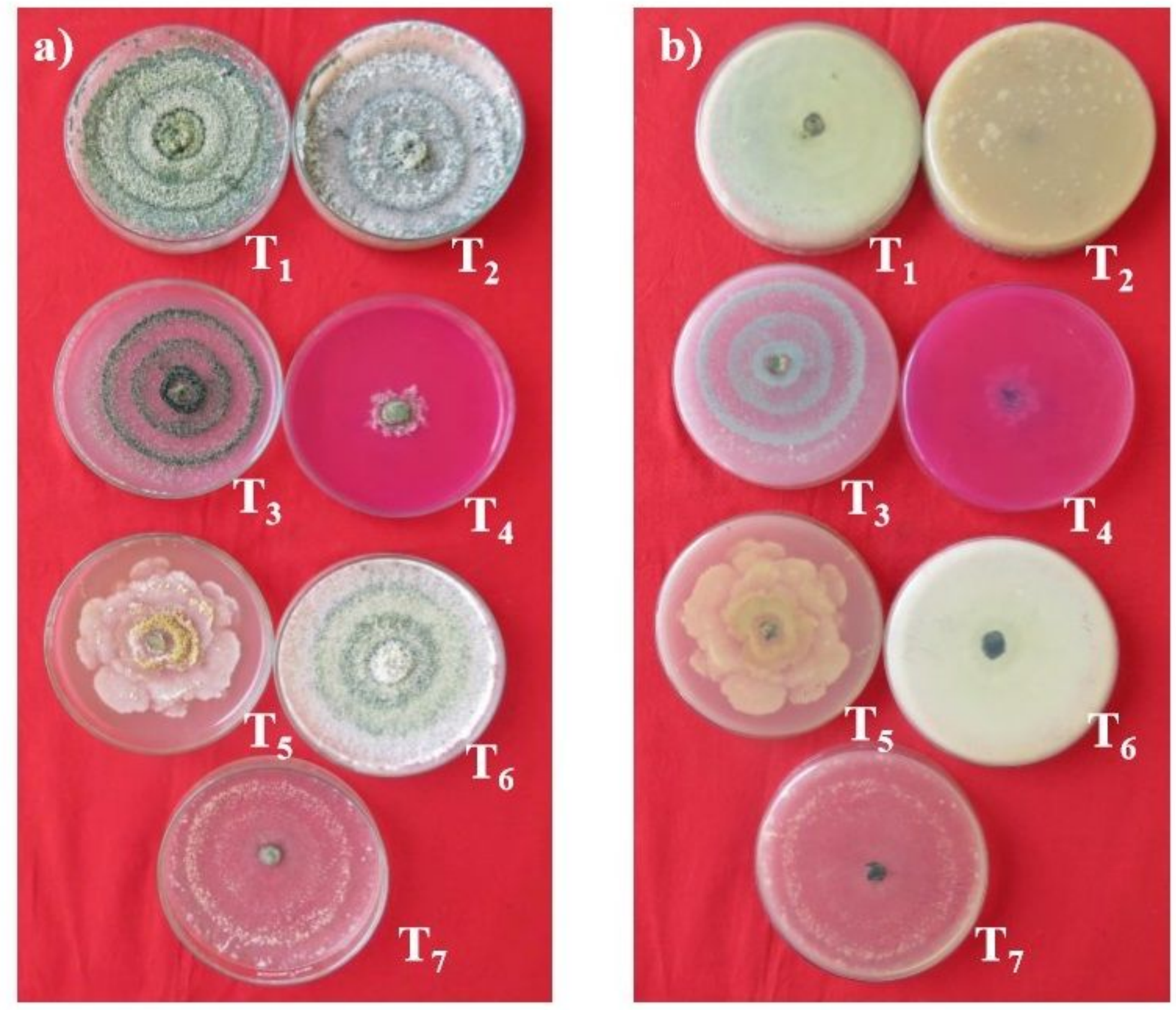

Figure 6

a) Colony appearance b) Pigmentation of $\mathrm{Kd}-\mathrm{Cu}$ isolate on different media 

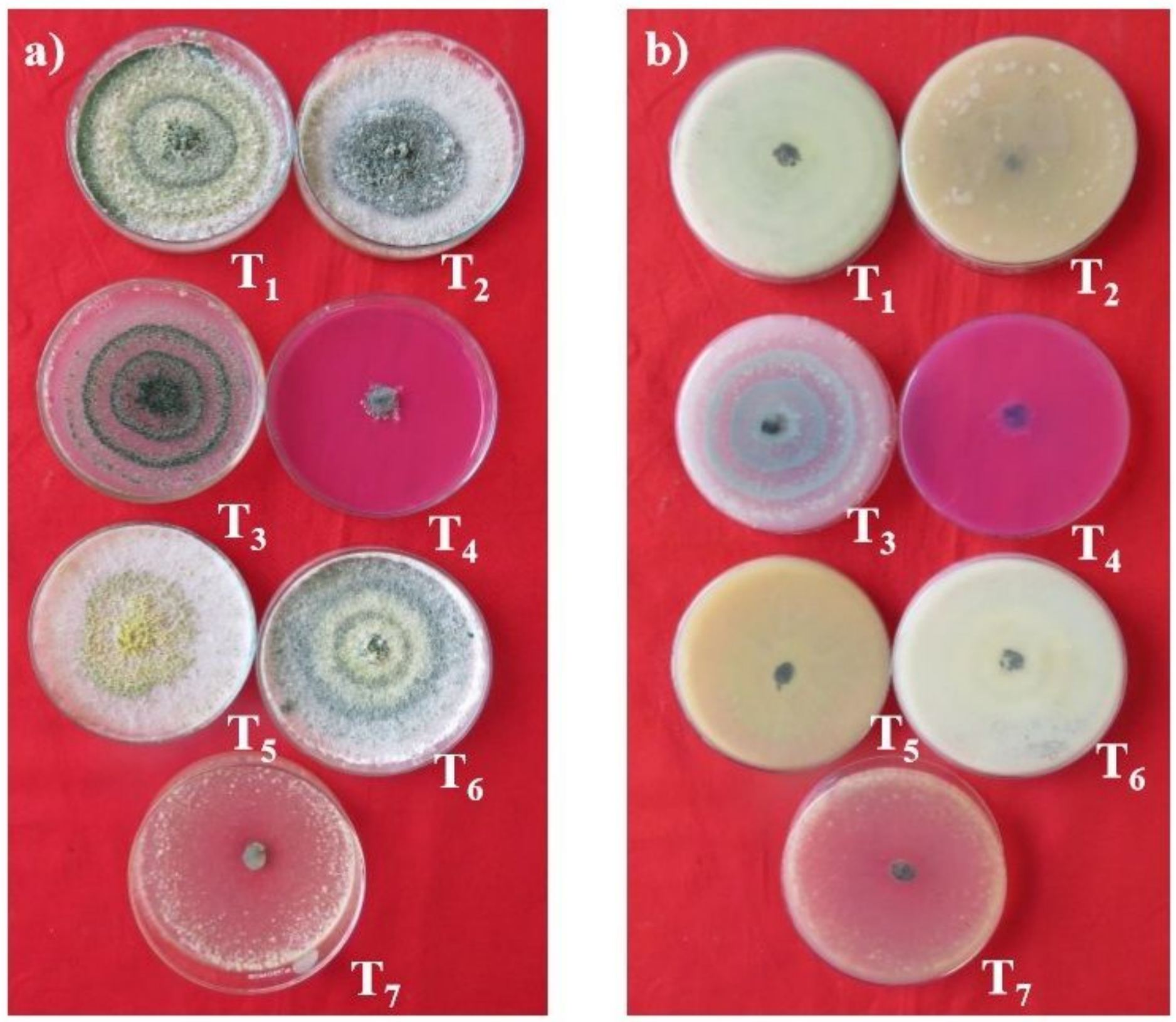

Figure 7

a) Mycelial growth of commercial isolate ( $T$. viride) b) Pigmentation on different media 


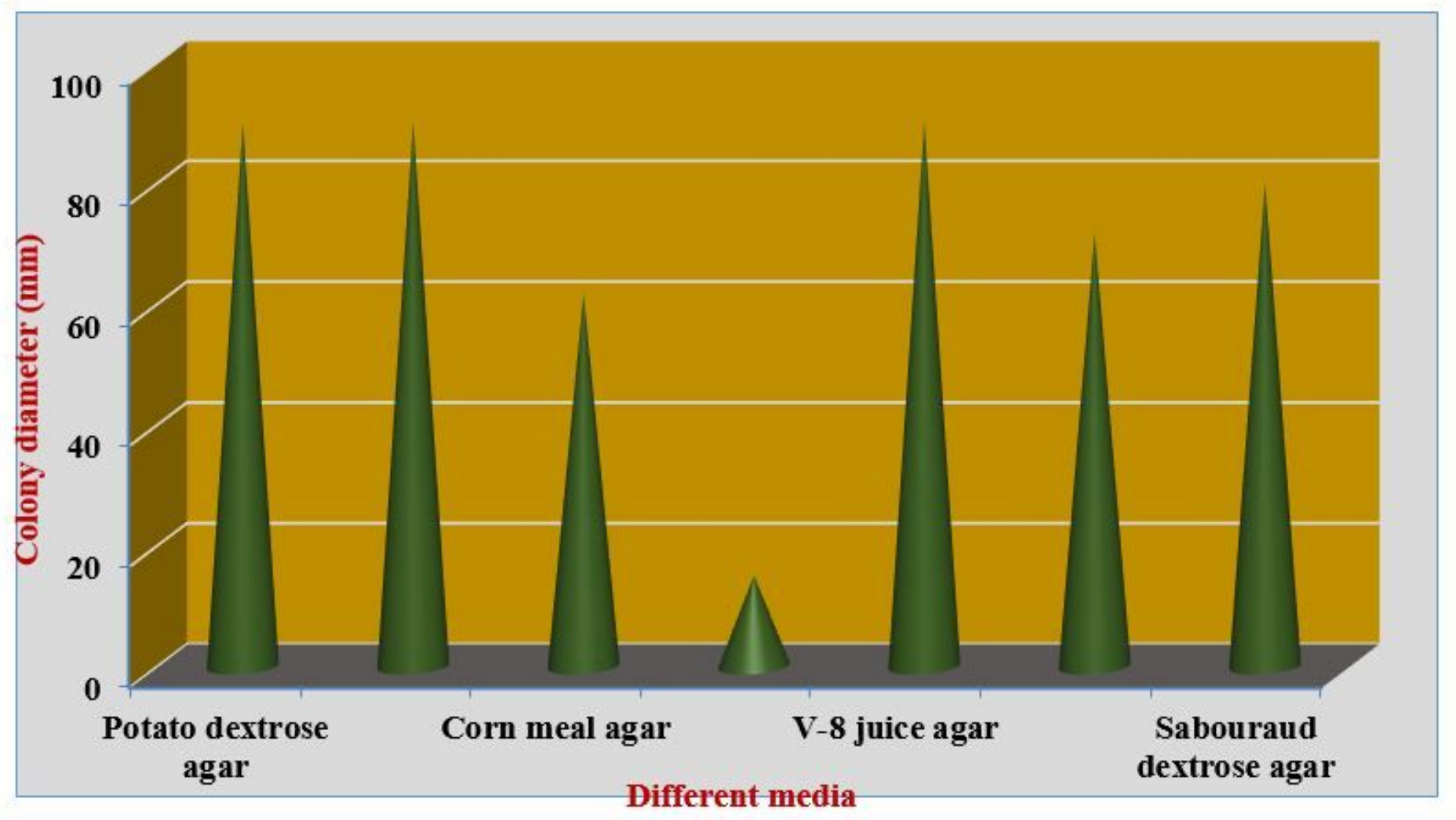

Figure 8

Mycelial growth of SMV isolate on different media

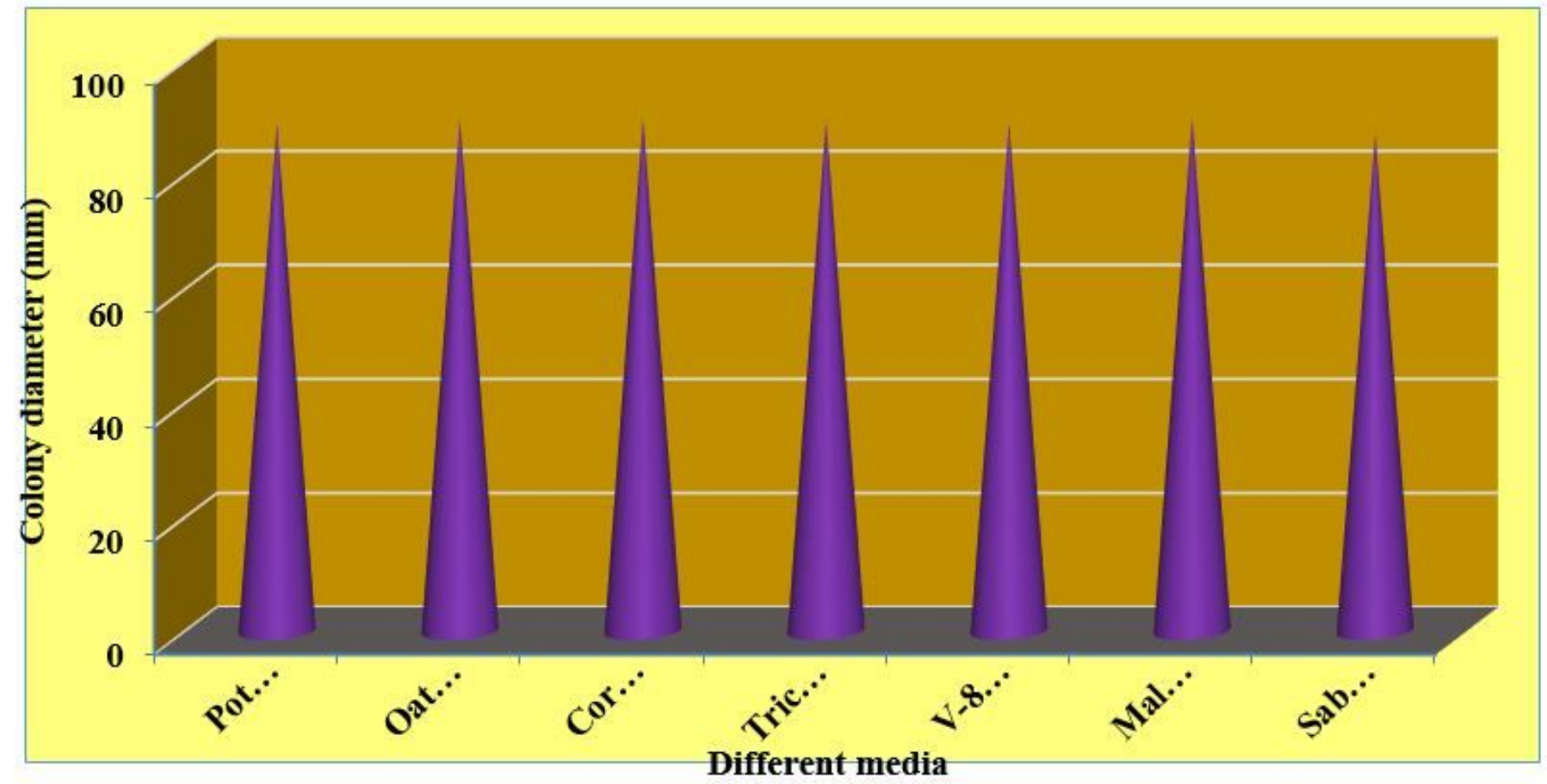


Figure 9

Mycelial growth of GMV isolate on different media

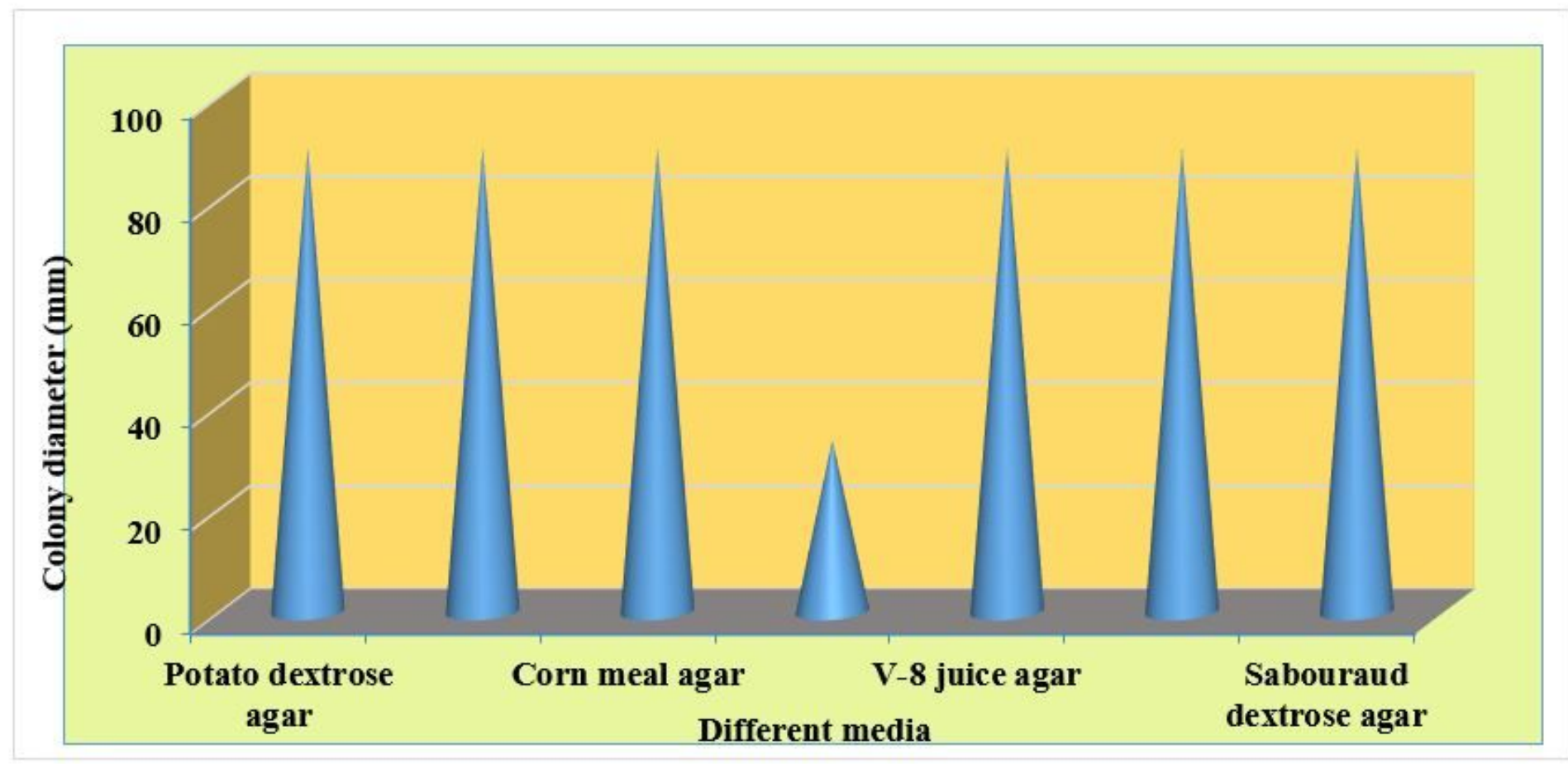

Figure 10

Mycelial growth of PSV isolate on different media 


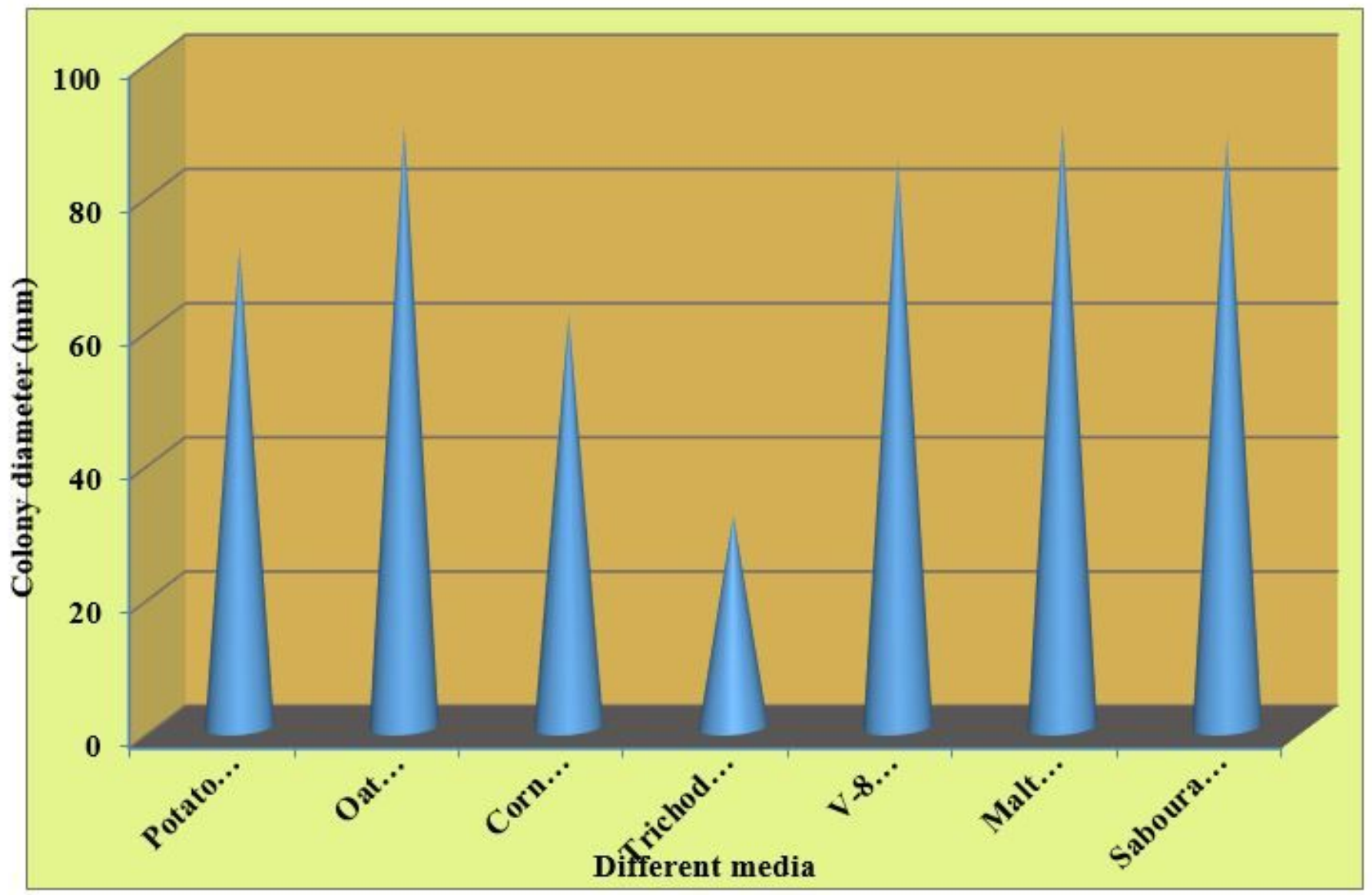

Figure 11

Mycelial growth of SDKd isolate on different media 


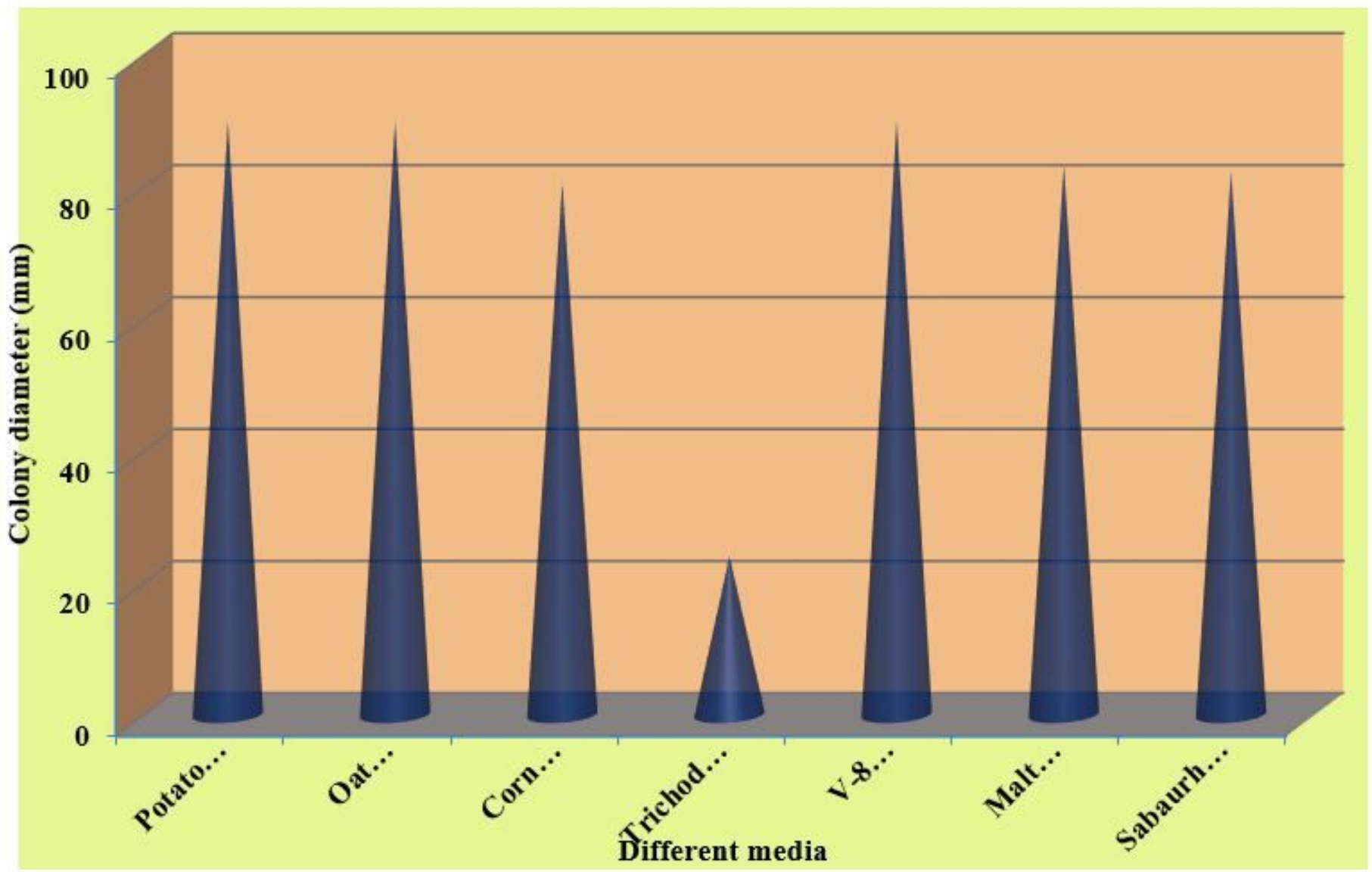

Figure 12

Mycelial growth of CPV isolate on different media 


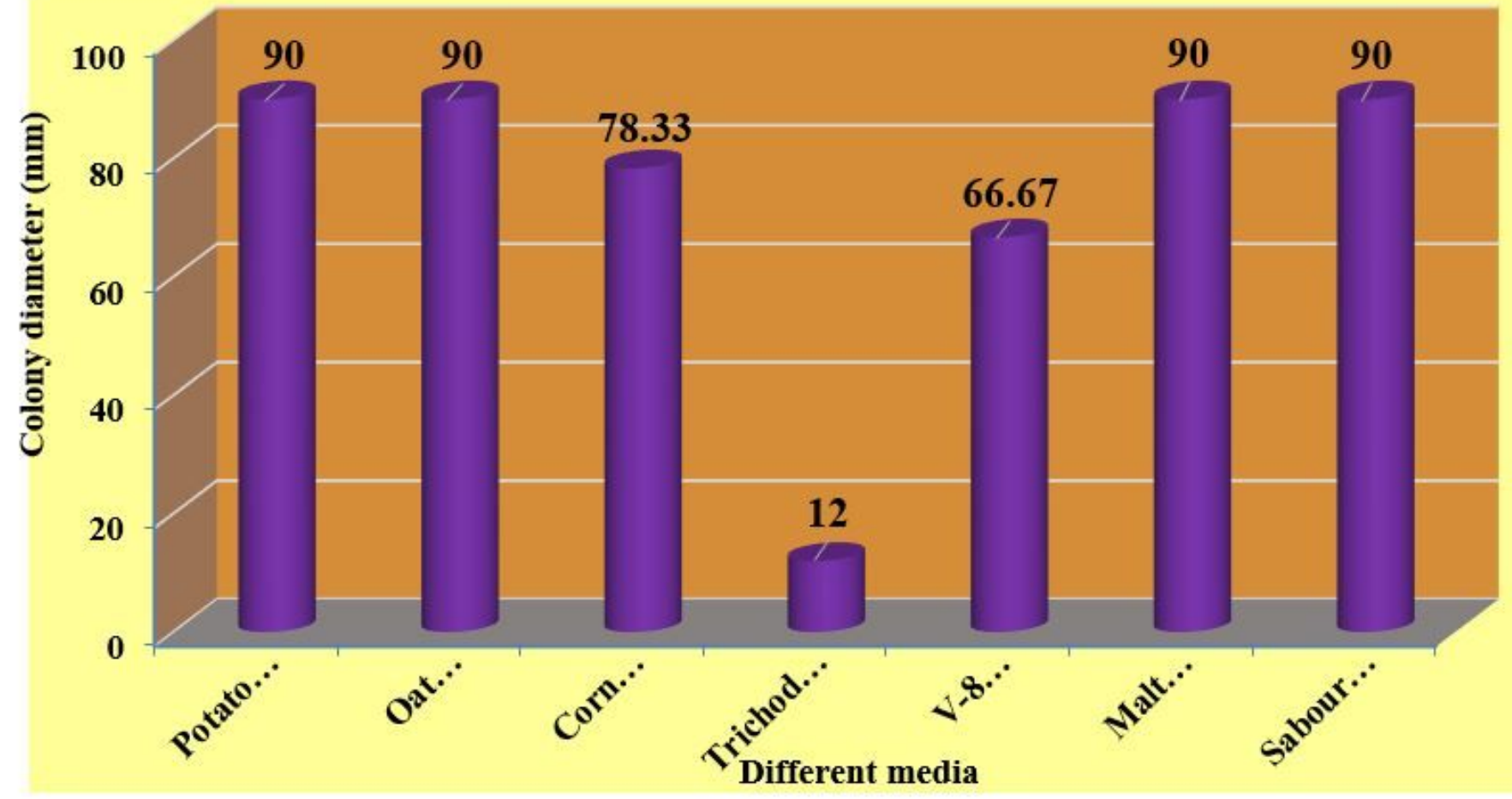

Figure 13

Mycelial growth of RKd-Cu isolate on different media

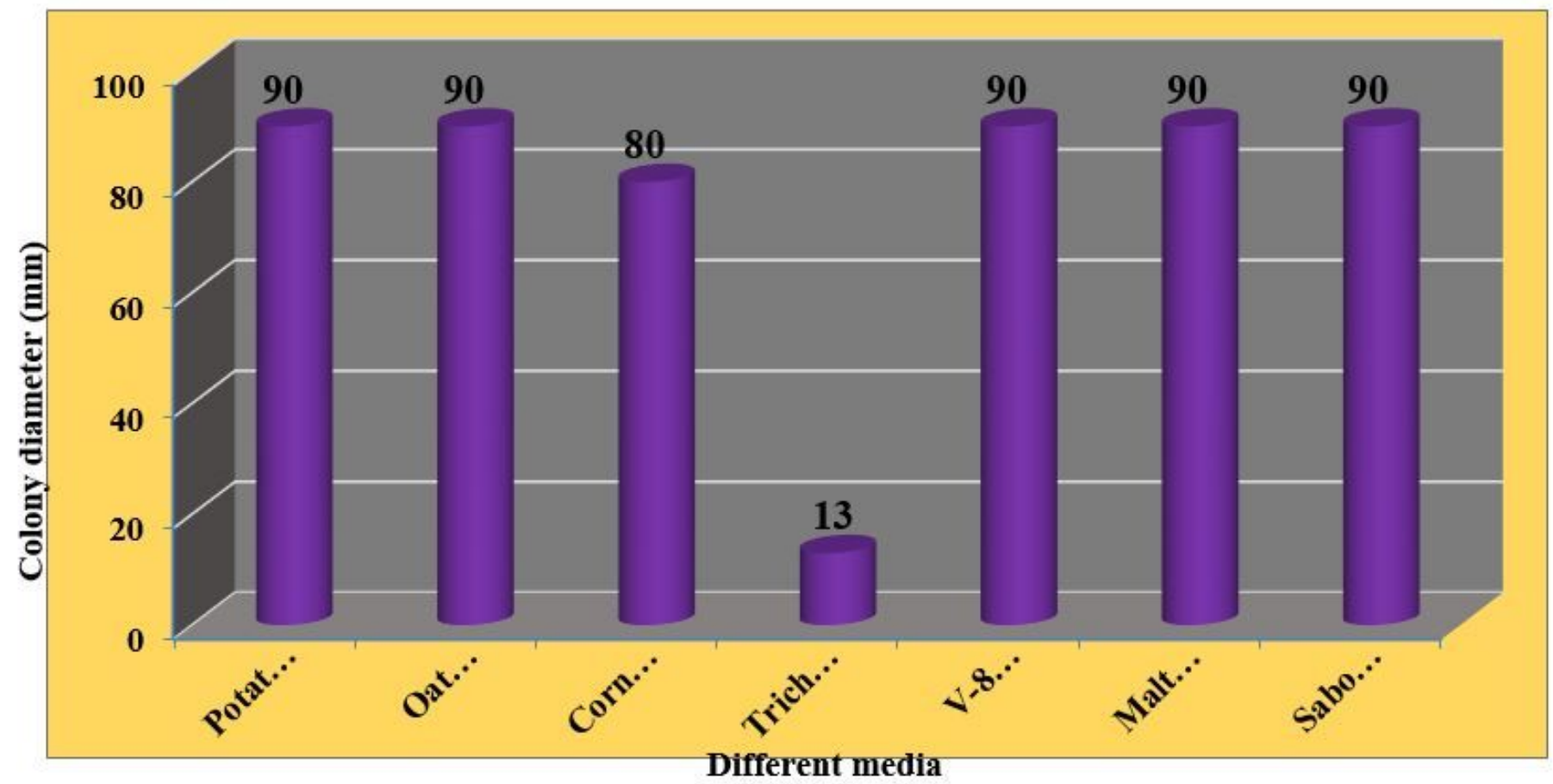

Figure 14 
Mycelial growth of commercial isolate ( $T$. viride) isolate on different media 